\title{
Physiological Changes Induced by Long Term Administration of Saccharin Compared with Aspartame to Male Albino Rats
}

\author{
Inas Z.A. Abdallah \\ Nutrition and Food Science Dept., Faculty of Home Economics \\ Helwan University
}

\begin{abstract}
:
Artificial sweeteners have been in use by food industries for a long time. Safety concerns raised about artificial sweeteners since they are widely used nowadays. The present work aims to study the possible changes in body weight, blood picture, liver functions, blood glucose and liver glycogen content as well as histopathological changes induced in liver and urinary bladder of male albino rats after administration of two artificial sweeteners (saccharin or aspartame). Male rats were administered saccharin $(50 \mathrm{mg} / \mathrm{kg}$ b.w.) or aspartame (100 mg/kg b.w.) daily by intragastric gavage for 14 weeks. The results revealed that both saccharin and aspartame provoked highly significant reduction in body weight gain \%. Saccharin exerted highly significant reduction in haemoglobin $(\mathrm{Hb})$ level, haematocrit (Hct\%) and red blood cells (RBCs) count, while aspartame induced insignificant changes in all haematological parameters. Alanine aminotransferase (ALT) and aspartate aminotransferase (AST) activity levels were significantly increased with saccharin and aspartame. Alkaline phosphatase (ALP) levels in serum showed slightly insignificant increase by saccharim administration, while aspartame caused a significant rise in ALP. Blood glucose level of rats given saccharin significantly dropped, while aspartame caused a significant elevation in blood glucose level. Liver glycogen content of rats given saccharin significantly increased, while aspartame caused a significant reduction in liver glycogen content. Microscopic examination of liver sections showed lymphocytic and macrophages infiltration of the portal traid in rats administered saccharin, while aspartame group showed no histopathological changes except slight hydropic degeneration of hepatocytes. Urinary bladder sections of rats administered saccharin revealed proliferation of the mucosal epithelial cells into papillary invaginated projections with highly vascularized connective tissue core and mononuclear inflammatory cells infiltration, while aspartame group showed no histopahtological alterations. It could be recommended that the use of saccharin as an artificial sweetener should be restricted, while aspartame should not be administered to diabetic. When it is necessary to use artificial sweeteners, fresh fruits and vegetables should be ingested as they act as scavengers for the liberated free radicals and help to delay the postprandial rise in blood glucose level.
\end{abstract}

\section{Introduction:}

Food additives are substances not normally found in foods which are added to extend shelf life, and improve flavour, colour and texture or stweeten food. Most highly processed foods cannot be made without them. Additives include antioxidants, preservatives, sweeteners, colourants, flavors, emulsifiers and stabilizers (Duyff, 2002).

Sweeteners could be classified as natural nutritive and artificial non-nutritive sweeteners. Nutritive sweeteners include monosaccharides, disaccharides and sugar alcohols from either natural or refined sources. White sugar, brown sugar, honey, corn syrup, glucose, fructose, lactose, maltose, sorbitol and xylitol are just some of the many nutritive sweeteners used in foods (Wardlaw, 2000). Non-nutritive sweeteners are also referred to as intense sweeteners, very low caloric or alternative sweeteners. These were discovered in the last century, beginning with saccharin which was discovered in 1879 , later, this was followed by many other artificial sweeteners including, sucralase, alitame, cyclamate, acesulfame-k and aspartame (Marion and Franz, 1993).

There are various reasons why sweeteners are used. In previous times, there was a medical need and purpose for developing artificial sweeteners, but today 
people increasingly choose low-calorie products to reduce their calorie intake. Studies have shown that more than half of the populations prefer artificially sweetened foodstuffs (Hinson and Nicol, 1992).

Saccharin is the oldest of the nonnutritive artificial sweeteners. It is characterized by being non caloric intense artificial sweetener as it has 300-500 times the sweetness of sucrose, but it has a slightly bitter aftertaste (Cook-Fuller, 2000). It has now been in use for over one hundred years and is still of the most important and widely used sweeteners (Spillance, 1996). Saccharin is a very stable compound with respect to heat and time so that it can be used in hot beverages and in food processing that involves application of high temperature such as canned vegetables, bakery products and reduced sugar jams (Mitchell and Pearson, 1991).

There are different forms of saccharin including sodium saccharin, calcium saccharin, potassium and acid saccharin. Sodium saccharin is more often used as it is more palatable (Reynolds and Martindale, 1989). The accepted daily intake of saccharin is $2.5 \mathrm{mg} / \mathrm{kg}$ body weight (Fowlkes and Carter, 1994).

Saccharin has been found to cause bladder cancer in male rats and is considered a possible carcinogen by the American Environmental Protection Agency. In the US, food containing saccharin must be labeled with a warning that use of this product may be hazardous to health and has caused cancer in laboratory animals (Williams, 2002).

Aspartame is one of the most widely used of the new sweeteners, discovered in 1965, produced commercially from the methyl ester of two amino acids, L-aspartic and L-phenyl alanine (Wardlaw and Kessel, 2002). It is an artificial sweetener possessing 180-200 times the sweetness potency of sucrose and has a calorie value of $4 \mathrm{Kcal} / \mathrm{g}$. Aspartame was approved by the Food and Drug Administration (FDA) in 1981 (American Dietetic Association, 1998). It was approved in Egypt by the Nutrition Institute in 1985 (Ismail and El-Gabry, 1996).

In a dry powder form, aspartame is relatively stable. However, on exposure to moisture, elevated temperature or extremes of
$\mathrm{pH}$, the esterified dipeptide is converted nonenzymatically into a variety of decomposed products (Lipton et al., 1991). Aspartame is used mostly in foods that don't require cooking or baking such as puddings, gelatins, frozen desserts, yogurt, toppings and fillings in precooked bakery goods and cookies, carbonated and powdered soft drinks, instant tea and coffee, breath mints, chewing gum and as a substitute for granulated sugar. However, FDA presented a warning label regarding the potential toxicity of aspartame in patients with phenylketonuria and liver diseases (Duyff, 2002). The accepted daily intake recommended by the FDA is $50 \mathrm{mg} / \mathrm{kg}$ body weight/day (Leon et al., 1989).

Clinically, chronic exposure to aspartame was reported to cause headache, blurred vision, epileptic tits and brain tumours as well as eye problems, numbness, insumnia, memory loss, nausea, slurred speech, personality changes, loss of energy, hyperactivity and hearing problems (VanDen-Eden et al., 1994). Furthermore, aspartame may adversely affect the capacity to control glucose metabolism in diabetic persons causing poor diabetic control and even may lead to precipitation of clinical diabetes in susceptible persons (Sardesai, 1986).

The aim of this work was to study the biochemical and histological changes induced by long term intake of a recently used commercial sweetener; aspartame and compare it with another known sweetener; saccharin to evaluate their hazardous effects on male albino rats.

\section{Material and Methods}

Thirty six male albino rats of Sprague Dawley strain, weighing (100-120g) were obtained from Helwan Research Station, Vaccines Association, Ministry of Health, Egypt. Sodium saccharin $\left(\mathrm{C}_{7} \mathrm{H}_{4} \mathrm{NO}_{3} \mathrm{SNa}\right)$ was purchased from El-Gomhoriya Pharm. and Chem. Ind. Comp. Cairo, Egypt and aspartylL-phenylalanine methyl ester $\left(\mathrm{C}_{4} \mathrm{H}_{18} \mathrm{~N}_{2} \mathrm{O}_{5}\right)$ was provided by El-Amriya Pharm. Ind. Comp., Alex. in powder forms.

\section{Experimental design:}

Animals were housed in stainless steel cages. They were kept under the same 
controlled laboratory conditions of temperature $\left(25^{\circ} \mathrm{C}\right)$, lighting and ventilation. All rats were fed on basal diet with the following ingredients and percentage: protein (casein) $20 \%$, corn oil $10 \%$, vitamin mixture $1 \%$, salt mixture $4 \%$, fiber (cellulose) $5 \%$ and the remainder is corn starch (Reeves et al., 1993). After one week, the rats were divided equally into three main groups each of 12 rats as follows:

1- Control group : Normal rats.

2- Saccharin group : Each rat orally received a daily does of $50 \mathrm{mg} / \mathrm{kg}$ b.w. sodium saccharin dissolved in distilled water according to Mitchell and Pearson (1991) through a stomach tube for 14 weeks .

3- Aspartame group : Each rat orally received a daily does of $100 \mathrm{mg} / \mathrm{kg}$ b.w. aspartamedissolved in distilled water accordingto Powers and Laine (1987) through a stomach tube for 14 weeks .

Body weights of rats were obtained at weekly intervals, and the amounts of sweeteners administrated were adapted according to the body weights on the basis of 50 and $100 \mathrm{mg} / \mathrm{kg}$ b.w. of saccharin and aspartame respectively.

\section{Blood and tissue sampling:}

Blood was obtained after 12 hours fasting, from all rat groups using the orbital sinus technique and used for haematological and biochemical parameters. The heparinized blood was freshly used for blood count assay. Haemoglobin concentration and haematocrit level were determined according to Dacie and Lewis (1975). The blood samples were centrifuged for $10 \mathrm{~min}$ at $3000 \mathrm{rpm}$ and the supernatant sera were separated for biochemical analysis.

Separated serum samples were used for determination of glucose enzymatically (Trinder, 1969), alanine aminotransferase (ALT) and aspartate aminotrasferase (AST) activities (Reitman and Frankel, 1957) and alkaline phosphatase (ALP) activity level (Belfield and Goldberg, 1971).

After collection of blood, the animals were dissected and tissues (liver and urinary bladder) were got out. The analysis also included determination of glycogen content in liver (Hassid and Abraham, 1957).

\section{Histological study:}

Specimens from liver and urinary bladder were fixed immediately in $10 \%$ neutral buffered formalin, dehydrated in different grades of alcohol, cleared in xylol, embedded in paraffin wax, sectioned at 4-6 $\mu$ thick and stained with haematoxylin and Eosin (Bancroft et al., 1996) and examined microscopically.

\section{Statistical analysis:}

All the data were expressed as mean \pm standard error (SE). The comparison between groups was performed with the Student ' $t$ ' test (Snedecor and Cochron, 1989).

\section{Results}

Table(1): Effect of saccharin or aspartame on body weight gain percent in different rat groups.

\begin{tabular}{|c|c|}
\hline $\begin{array}{c}\text { Experimental } \\
\text { groups }\end{array}$ & Body weight gain \% \\
\hline Control & $82.97 \pm 5.82$ \\
& $(100 \%)$ \\
\hline Saccharin & $56.15 \pm 3.11^{* *}$ \\
& $(67.68 \%)$ \\
\hline Aspartame & $61.66 \pm 2.95^{* *}$ \\
& $(74.32 \%)$ \\
\hline
\end{tabular}

- Each value represents the mean of 12 rats \pm SE.

- * Significant difference compared to control at $\mathrm{P}<0.05$ and $* * \mathrm{P}<0.01$ as judged by Student " $\mathrm{t}$ " test.

The body weight gain percent in rats administered saccharin or aspartame was presented in Table (1). The results revealed highly significant reduction in body weight gain $\%$ in both saccharin and aspartame groups with percentages equal to 67.68 and $74.32 \%$, respectively when compared to the control group.

Table (2) showed haematological parameters in rats administered saccharin or aspartame. Saccharin exerted highly significant reduction in $\mathrm{Hb}$ concentration, $\mathrm{Hct} \%$ and RBCs count with percentage $74.92,80.73$ and $80.67 \%$ respectively and non significant changes in WBC when compared to control rats. Meanwhile, aspartame induced non-significant changes 
Table (2): Effect of saccharin or aspartame on haematolgoical parameters in different rat groups.

\begin{tabular}{|c|c|c|c|c|}
\hline $\begin{array}{c}\text { Experimental } \\
\text { groups }\end{array}$ & $\begin{array}{c}\text { Hb } \\
(\mathbf{g} / \mathbf{d l})\end{array}$ & $\begin{array}{c}\text { Hct } \\
(\boldsymbol{\%})\end{array}$ & R.B.Cs $10^{6}$ & W.B.C $10^{3}$ \\
\hline Control & $14.75 \pm 0.97$ & $38.61 \pm 1.91$ & $7.19 \pm 0.37$ & $7.61 \pm 0.62$ \\
& $(100 \%$ & $(100 \%)$ & $(100 \%)$ & $(100 \%)$ \\
\hline Saccharin & $11.05 \pm 0.58^{* * a}$ & $31.17 \pm 0.98^{* * a}$ & $5.8 \pm 0.19^{* * *}$ & $6.92 \pm 0.61$ \\
& $(74.92 \%)$ & $(80.73 \%)$ & $(80.67 \%)$ & $(90.93 \%)$ \\
\hline Aspartame & $14.43 \pm 1.16$ & $36.3 \pm 2.2$ & $6.96 \pm 0.58$ & $7.31 \pm 0.69$ \\
& $(97.83)$ & $(94.02 \%)$ & $(96.80 \%)$ & $(96.06 \%)$ \\
\hline
\end{tabular}

- Each value represents the mean of 12 rats + SE.

- * Significant difference compared to control at $\mathrm{P}<0.05$ and ** $\mathrm{P}<0.01$ as judged by Student " $\mathrm{t}$ " test.

- a: Significant difference between saccharin and aspartame groups.

Table (3): Effect of saccharin or aspartame on serum activity levels of alanine aminotransferase (ALT), aspartate aminotransferase (AST) and alkaline phosphatase (ALP) in different rat groups.

\begin{tabular}{|c|c|c|c|}
\hline Experimental groups & $\begin{array}{c}\text { ALT } \\
(\boldsymbol{\mu} \text { mole/dl/min) }\end{array}$ & $\begin{array}{c}\text { AST } \\
(\boldsymbol{\mu} \mathbf{~ m o l e} / \mathbf{d l} / \mathbf{m i n})\end{array}$ & $\begin{array}{c}\text { ALP } \\
(\mathbf{U} / \mathbf{d l})\end{array}$ \\
\hline Control & $50.08 \pm 3.78$ & $150.39 \pm 7.13$ & $5.6 \pm 0.39$ \\
& $(100 \%)$ & $(100 \%)$ & $6.17 \pm 0.63$ \\
& $59.79 \pm 2.51^{*}$ & $169.41 \pm 4.49^{*}$ & $(110.18 \%)$ \\
\hline Saccharin & $(119.39 \%)$ & $(112.65 \%)$ & $6.59 \pm 0.11^{*}$ \\
& $65.87 \pm 5.92^{*}$ & $176.93 \pm 6.71^{*}$ & $(117.68 \%)$ \\
\hline
\end{tabular}

- Each value represents the mean of 12 rats + SE.

- * Significant difference compared to control at $\mathrm{P}<0.05$ and ** $\mathrm{P}<0.01$ as judged by Student " $\mathrm{t}$ " test.

in all parameters. There were significant differences between saccharin and aspartame groups in $\mathrm{Hb}$ level and $\mathrm{Hct} \%$, while the differences were non significant in RBCs and WBC count.

The activity levels of ALT, AST and ALP in serum of rats administered saccharin or aspartame are presented in Table (3). The data indicated significant increase in ALT and AST activity levels in both saccharin and aspartame groups with percentages equal to 119.39 and $131.53 \%$ for ALT and 112.65 and $117.65 \%$ for AST in saccharin and aspartame group, respectively. Administration of aspartame to rats induced significant increase in ALP level when compared to control with percentage $117.68 \%$. Meanwhile, saccharin induced slightly insignificant increase in ALP level when compared to the control group.

The glucose concentration and liver glycogen content of rats administered saccharin or aspartame are shown in Table 4. The data indicated a significant reduction in glucose concentration as a result of saccharin administration with percentage of $80.67 \%$ when compared to control, meanwhile aspartame induced highly significant elevation with percentage of $145.02 \%$ when compared to control. There was significant difference between saccharin and aspartame groups.

Table (4): Effect of saccharin or aspartame on blood glucose concentration and liver glycogen content in different rat groups.

\begin{tabular}{|c|c|c|}
\hline $\begin{array}{c}\text { Experimental } \\
\text { Groups }\end{array}$ & $\begin{array}{c}\text { Glucose } \\
\text { (mg/dl) }\end{array}$ & $\begin{array}{c}\text { Liver glycogen } \\
\text { (mg/g wet liver) }\end{array}$ \\
\hline Control & $90.71 \pm 6.67$ & $7.97 \pm 0.62$ \\
& $(100 \%)$ & $(100 \%)$ \\
\hline Saccharin & $73.18 \pm 4.49^{* a}$ & $11.63 \pm 1.13^{\mathrm{a}}$ \\
& $(80.67 \%)$ & $(145.92 \%)$ \\
\hline Aspartame & $131.6 \pm 10.17^{* *}$ & $5.48 \pm 0.52^{*}$ \\
& $(145.08 \%)$ & $(68.76 \%)$ \\
\hline
\end{tabular}

- Each value represents the mean of 12 rats \pm SE.

- * Significant difference compared to control at $\mathrm{P}<0.05$ and ** $\mathrm{P}<0.01$ as judged by Student " $\mathrm{t}$ " test.

- a: Significant difference between saccharin and aspartame groups. 
Rats administered saccharin showed elevation in liver glycogen content with percentage of $145.92 \%$, while group administered aspartame showed significant reduction with percentage of $68.76 \%$ when compared to control. Significant difference between saccharin and aspartame groups was recorded in liver glycogen content.

\section{Histological results:}

Microscopical examination of liver from control rats revealed the normal histological structure of hepatic lobule, which consists of central vein and concentrically arranged hepatocytes (Fig. 1). Portal traid presents between three hepatic lobules. Concerning liver of rats administered saccharin showed portal infiltration with

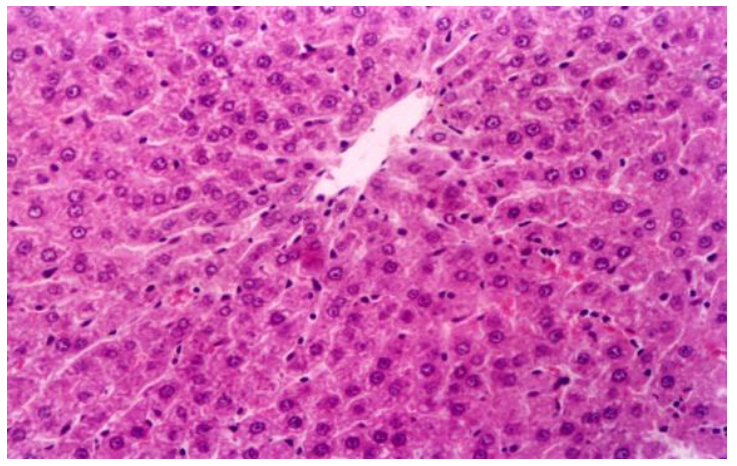

Fig.(1): Liver of control rats showing the normal histological structure of hepatic lobule from central vein and hepatocytes.

(H\&E stain X 200)

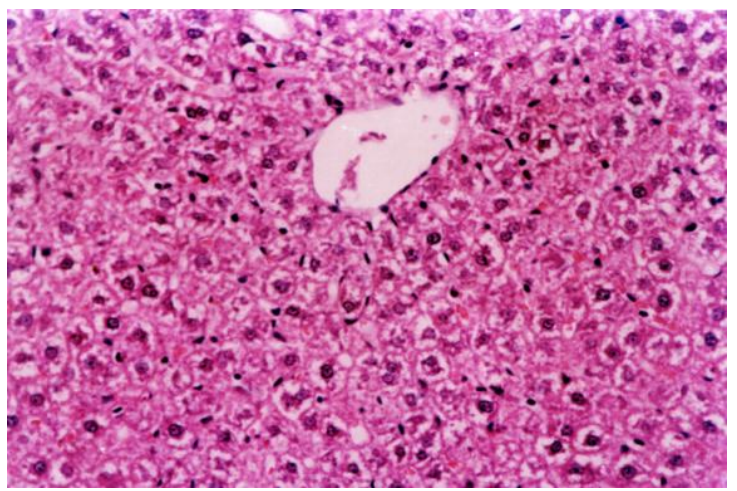

Fig.(3): Liver of rats administered aspartame showing slight hydropic degeneration of hepatocytes.

(H\&E stain X 200) mononuclear inflammatory cells mainly lymphocytes and macrophages (Fig. 2). Liver of rats administered aspartame showed slight hydropic degeneration of hepatocytes (Fig.3)

Microscopical examination of urinary bladder from control group showed no histological alterations (Fig. 4). Bladder sections of rats administered saccharin revealed proliferation of the mucosal epithelial cells into papillary invaginated projections (Fig. 5) and fibrous connective tissue core which rich in well developed dilated blood vessels as well as mononuclear inflammatory cells infiltrations (Fig. 6). Meanwhile, the bladder sections of rats administered aspartame showed no histopathological alterations (Fig.7).

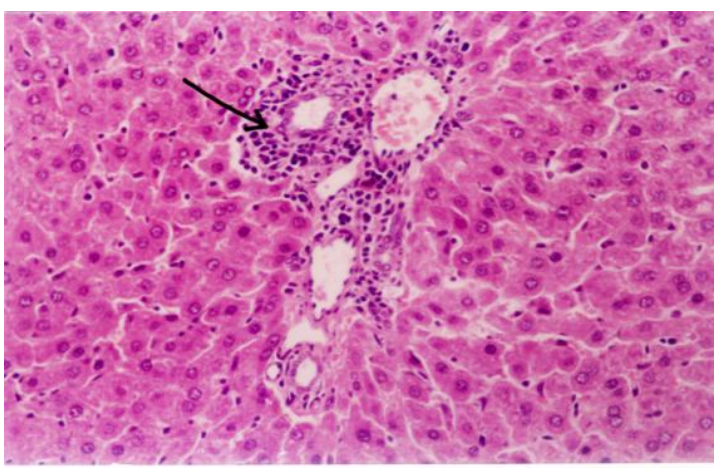

Fig.(2): Liver of rats administered saccharin showing portal infiltration with mononuclear inflammatory cells.

(H\&E stain X 200).

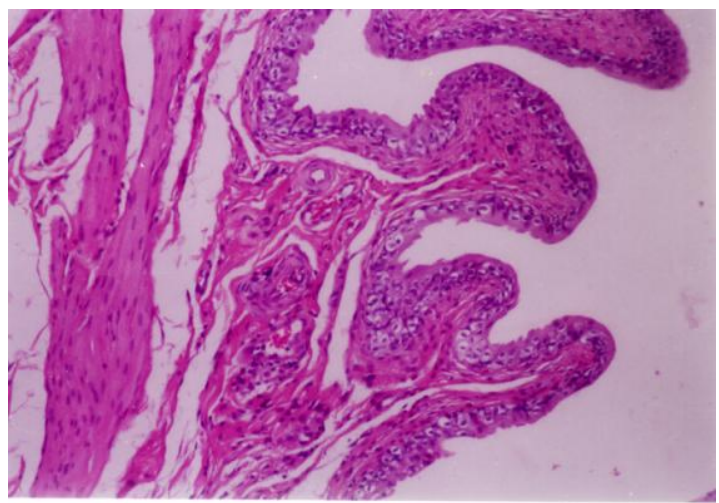

Fig.(4):Urinary bladder of rats from control group showing no histological changes.

(H\&E stain X 100) 


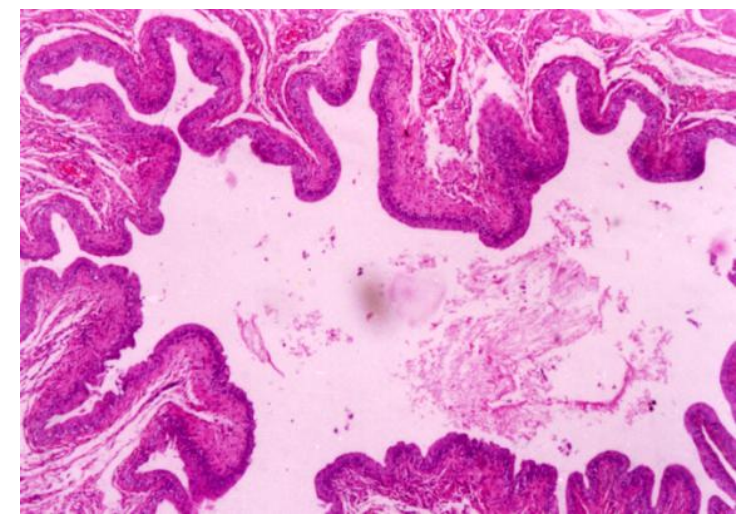

Fig.(5): Urinary bladder of rats administered saccharin showing proliferated papillary projections of the mucosa associated with fibrous connective tissue core.

(H\&E stain x 40)

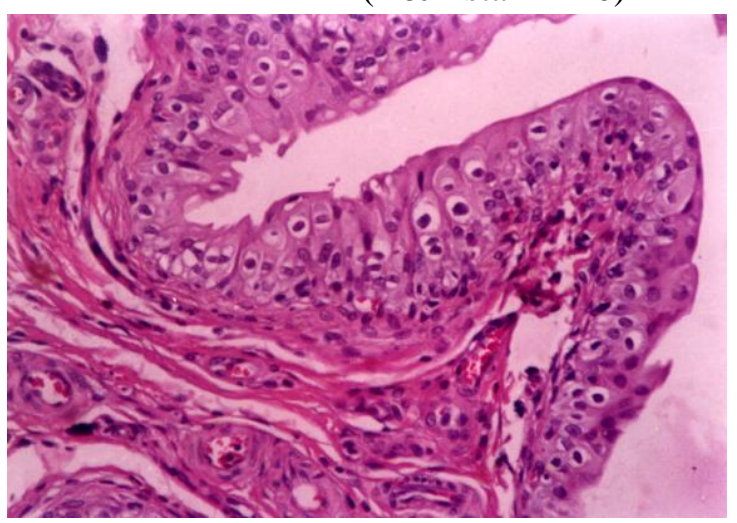

Fig.(7): Urinary bladder of rats administered aspartame showing no histological changes.

(H\&E stain x 200).

\section{Discussion}

Artificial sweeteners are widely used nowadays, when the sensitivity of the people to the general health increased, the subject of sweeteners as food additives will take dangerous and effective dimension. It is almost impossible to follow a diet which is completely free from sweeteners and other food additives. The toxicity of sweeteners has become increasing and has attracted the concern of many scientists to study their toxic effect. Several previous studies have revealed that the use of artificial sweeteners may entail some hazards to the users (Mukhopadhyay et al., 2000). These include incidence of bladder carcinoma in mice and rats and other tumors

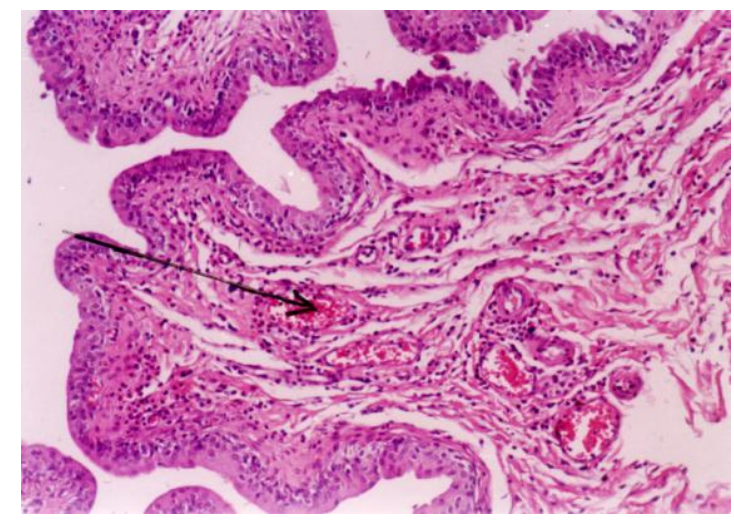

Fig.(6): Higher magnification of Fig.5 showing the highly vascularized connective tissue core (arrows) and mononuclear inflammatory cells infiltration. (H\&E stain x 100)

in different tissues as well as reports of induction of hyperplasia (Cohen et al., 2000).

The present results showed highly significant reduction in body weight gain percent in both aspartame and saccharin groups when compared to the control group. In agreement with this result Dib et al. (1996) reported a significant reduction in body weight of rats $(50 \%)$ after administration of sodium saccharin for 14 days. Garland et al. $(1991 \mathrm{~b})$ also noted that body weights of saccharin treated male and female rats were significantly lower than the controls after 12 weeks treatment. They attributed this weigh loss to reduce food consumption per day.

On the other hand, Rolls (1991) reported that both short term and long term studies have shown that consumption of aspartame sweetened foods or drinks is associated with a reduction in food intake. Blundell and Hill (1986) concluded that aspartame may lead to a loss of appetite.

In the present study, saccharin group showed insignificant changes in WBCs level and highly significant reduction in $\mathrm{Hct} \%, \mathrm{Hb}$ and RBCs levels, meanwhile aspartame group showed insignificant changes in all parameters. In agreement with these results, Garland et al. (1991 a) reported that parental rats and their off-springs fed on sodium saccharin for 30 days developed anaemia as indicated by the decrease in red blood cells and haemoglobin . 
On the other hand, Leon et al. (1989) evaluated the safety of administration of aspartame in a dose of $75 \mathrm{mg} / \mathrm{kg} / \mathrm{day}$ in male and female volunteers for a period of 24 weeks. They found no significant changes in complete blood cell count that included white blood cells that were reported within the normal ranges. The haematological disorders manifested mainly by saccharin may be attributed to the prevention of red blood cell synthesis via inhibition of erythropoeisis in the bone marrow with resultant development of anaemia (Prasad and Rai, 1987).

The present study revealed that administration of the two sweeteners induced hepatic cellular changes. This is proved by a significant increase in ALT and AST activities in both saccharin and aspartame groups when compared to the control group. Furthermore, aspartame group showed significant increase in ALP level, while saccharin group showed slightly non significant increase in ALP level when compared to the control group. These results were in agreement with Kamal et al. (2000) who noted that the activities of AST and ALP increased significantly after administration of aspartame to healthy adult albino rats for 5 weeks. The elevation in serum aminotransferase activities could be due to drastic physiological effects caused by free radicals interaction with cellular membranes or may be related to breakdown of liver parenchyma (Gray et al., 1985).

In addition, Negro et al. (1994) reported elevated serum concentrations of liver enzymes after the oral administration of three different drugs, of which saccharin was the only common constituent. The liver cells play an important role in both synthesis and secretion of ALP into the bile. Therefore, the alterations in ALP activity caused by aspartame and to a lesser extent by saccharin may be attributed to early cholestatic liver damage which primarily affects the liver parenchyma, thus making ALP a sensitive index in the diagnosis of infiltrative diseases (El-Elaimy and El-Nabi, 1990).

In the obtained results, there was significant reduction in blood glucose level and significant elevation in liver glycogen content of saccharin group when compared to the control group. This finding was in agreement with that reported by Horwitz et al. (1988) in animals who found that chronic consumption of large amounts of saccharin might reduce blood glucose concentration. Bailey et al. (1997) reported reduction of hyperinsulinemia, decrease the insulin resistance and improve glycemic control during saccharin consumption in hyperglycemic obese mice.

The present results also revealed that administration of aspartame to rats induced highly significant elevation in blood glucose level and significant reduction in liver glycogen content when compared to the control group. This was in agreement with Kamal et al. (2000) who reported significant increase in serum glucose levels of healthy and diabetic rat groups fed on $100 \mathrm{mg} / \mathrm{kg}$ b.w. /day aspartame for a period of 5 weeks. It was also reported that administration of oral doses of aspartame in normal humans lead to a significant rise of glucose but did not alter serum insulin (Carlson and Shah, 1989). The increased serum glucose level in aspartame group may be attributed to the amino acids composition of aspartame where phenylalanine is considered to be both glucogenic and, ketogenic, while aspartic acid considered to be partially glucogenic amino acid and consequently converted to glucose (Devlin, 1997). The glycogenolytic effect of aspartame may be due to its direct effect on cell stimulating glycogenolysis or due to its effect on other cytoplasmic membranous organelles and the associated enzymes necessary for glycogen synthesis (Sulik, 1974).

The histological examination of liver sections of rats administered saccharin revealed that the portal triad was infiltrated with mononuclear inflammatory cells mainly lymphocytes and macrophages. The same observation was reported by Hassanin (1998) who noted that the portal tract in liver sections of rats received saccharin for six weeks showed moderate infiltration by mononuclear inflammatory cells, mainly lymphocytes and there was vascular congestion. This observation was contradicted with the announcement reported by 
Shakoori etal. (1995) that administration of high $(260 \mathrm{mg} / \mathrm{kg}$ b.w.) and low dose $(65 \mathrm{mg} /$ $\mathrm{kg}$ b.w.) saccharin to male albino Swiss mice for 39 weeks caused hypertrophy of hepatic cells, their nuclei and nucleoli and excessive vacuolation of cell cytoplasm. The discrepancies observed between this study and the latter research study may be attributed to variations in the concentration and duration of saccharin administration.

In this study, aspartame produced slight hydropic degeneration of hepatocytes. This finding was in coincidence with the observation of El-Gengihi et al. (1993) who found that aspartame treated rats developed minimal hydropic degeneration of heaptocytes. Hertelendy et al. (1993) stated that aspartame was found to be rapidly metabolized with negligible toxicity and borderline liver decompensation. They marked that it might be used with relative safety. Liver has a major role in aspartame metabolism. Degeneration is a disturbance in the metabolism of the cell resulting in morphologic abnormalities. Hydropic degenerateion means that mitochondria is affected with the result of lack of energy (Abdin, 1981).

Histological examination of urinary bladder sections of rats administered saccharin revealed proliferation of the mucosal epithelial cells into papillary invaginated projections. Urinary bladder hyperplastic lesions were generally classified into, simple diffuse hyperplasia, focal or papillary hyperplasia, papilloma and carcinoma (Cohen, 1983). In this study, the hyperplasia was found to be mainly focal. In agreement with this result, Okamura et al. (1991) demonstrated both simple and focal hyperplasia of the transitional epithelium in rats received 5\% sodium saccharin in their diet for 10 weeks.

Moreover, Cohen and Ellwein (1991) observed that prolonged administration of sodium saccharin related to the development of bladder cancer as it was revealed to increase urothelial cell proliferation of adult rats. The proliferative effect of saccharin was found to be a dose and duration dependent (Murasaki and Cohen, 1981).

Sodium saccharin was reported to be a promoter of urinary bladder carcinogenesis in rats. This carcinogenic effect was found to be greater in males than in females especially when they kept on high dietary concentration of sodium saccharin from birth (Lewis et al., 1992). This finding in the saccharin administered rats may be attributed to the fact that sodium saccharin induces alkalization of urine $\mathrm{pH}>6.5$ and increases sodium ion concentration which increase the formation of silicate precipitates and/or crystals in the urine. Formation of such precipitates have been postulated to play crucial roles in the proliferative effect of sodium saccharin (Anderson, 1988 and Elcock and Morgan, 1993). Increased DNA synthesis leading to an increased turn over rate of urothelial cells and hyperplasia after prolonged intake of sodium saccharin was also considered to have important role (Debiec and Wang, 1990).

On the other hand, the present study revealed that examination of rats' urinary bladder received aspartame showed no histological changes. The same observations were reported by Hagiwara et al. (1984) and Ito et al (1989) who supported and confirmed the present study as they could not demonstrate any harmful effects on the urinary bladder after prolonged administration of aspartame to experimental animals.

From the present results it could be concluded that the intake of saccharin succeeded in reducing blood glucose level but caused evident inflammatory hepatic cells and severely affected the urinary bladder causing epithelium hypelplasia. While, equivalent doses of aspartame caused less and no histological changes in liver and urinary bladder respectively but induced elevation in blood glucose level.

Therefore, it could be recommended that the use of saccharin as an artificial sweetener should be restricted. On the other hand, aspartame should not be administered to diabetic due to its effect on blood glucose elevation, further investigations also should be conducted concerning its effect on other organs and its use for more prolonged periods. 


\section{References}

1. Abdin, F. (1981):- Cell and tissue damage. In "Abdin's General Pathology". $4^{\text {th }}$ ed., p. 7.

2. American Dietetic Association (ADA) (1998):- Use of nutritive and non-nutritive sweeteners. Journal of the American Dietetic Association, 98: 580.

3. Anderson, R.L. (1988):- Hypothesis of the mechanism of urinary bladder tumorgenesis in rat ingesting sodium saccharin. Food Chemical Toxicol, 26(7): 637-644.

4. Bailey, C.J., Day, C., Knapper, J.M., Turner, S.L. and Flatt, P.R. (1997):Antihyperglycemic effect of saccharin in diabetic ob/ob mice. Br. J. Pharmacol., 120(1): 74-78.

5. Bancroft, D., Stevens, A. and Turmer, R. (1996):- Theory and practice of histological technique, $4^{\text {th }}$ ed., Churchill Living Stone, Edinburgh, London, Melbourne.

6. Belfield, A. and Goldberg, D.M. (1971):Enzyme, 12, 561. C/F: Bio-Merieux, L'Etoile, France.

7. Blundell, J.E. and Hill, A.J. (1986):Paradoxical effects of an intense sweetener (aspartame) on appetite. Lancet, 1(8489): 1092-1093.

8. Carlson,H.E. and Shah, J.H. 1989):Aspartame and its constituent amino acids: effects on prolactin, cortisol, growth hormone, insulin and glucose in normal humans. Am. J. Clin. Nutr., 49(3): 421-432.

9. Cohen, S.M. (1983):- Pathology of experimental bladder cancer in rodents. In: The Pathology of Bladder Cancer. FL:CRC Press. Cohen, S.M. and Bryan, G.T. (Eds.), Boca Raton, p. 1-40.

10. Cohen, S.M. and Ellwein, L.B. (1991):Genetic errors, cell proliferation and carcinogenesis. Cancer Res., 51:6493-6505.

11. Cohen, S.M., Arnold, L.L.; Cano, M. Ito, M., Garland, E.M. and Shaw, R.A. (2000):- Calcium phosphate containing precipitate and the carcinogenicity of sodium salts in rats. Carcinogenesis, 21(4): 783792.

12. Cook-Fuller, C.C. (2000):- Low-calorie sweeteners. In "Nutrition", $11^{\text {th }}$ ed., Ann edi, USA, p.15,16.

13. Dacie, J.V. and Lewis, M.S. (1975):- In "practical Haematology" $6^{\text {th }}$ ed., Churchill Livingeston, London, New York, Ch.5. p. 37.

14. Debiec, R.M. and Wang, C.Y. (1990):Induction of DNA synthesis by sodium Phenobarbital, uracil and sodium saccharin in urinary bladder of the rats. Toxciol. App. Pharmacol., 105:345-349.

15. Devlin, T.M. (1997):- Textbook of Biochemistry: With clinical correlations. Wiley, John \& Sons, Inc. New York.

16. Dib, K., Oget, I., Wrisez, F., El-Jamali, A., Aguie-Aguie, G., Correze, C., Lambert, B. (1996):- Effects of sodium saccharin diet on fat-cell lipolysis: evidence for increased function of the adenylyl cyclase catalyst. Int. J. Obes. Relat. Metab. Disord., 20(1): 15-20.

17. Duyff, R.L. (2002):- American Dietetic Association Complete Food and Nutrition Guide. 2ed ed., John Wiley \& Sons, Inc., p. 127, 194-198.

18. Elcock,M. and Morgan, W. (1993):Update on artificial sweeteners and bladder cancer. Regulatory Toxicology and Pharmacology, 17: 35-43.

19. El-Elaimy,A. and El-Nabi,S.E.H. (1990):Imfluence of thiola on pesticide induced intoxication. II-preventive effect of liver damage. J. Environ. Sci., 1: 67-82.

20. El-Gengihi, T.M.; Ahmed, S.A. and Hamoudah, S. (1993):- Histological study of the effect of sweetener "Aspartame" on liver and kidneys of adult albino rats. The Egyptian Journal of Histology, 16(2): 309315.

21. Fowlkes, K.D. and Carter, G. (1994):Alternative sweeteners. Drug Consults, 86:162-167.

22. Garland, E.M., Kraft, P.L. Shapiro, R., Khachab, M., Patil, K., Ellwein, L.B. and Cohen, S.M. (1991 a):- Effects of in utero and postnatal sodium saccharin exposure on the nutritional status of the young rat. 1 . Effects at 30 days post-birth. Food Chem. Toxicol., 29(10): 657-667.

23. Garland, E.M., Shapiro, R. Kraft, P.L., Mattson, B.J., Parr, J.M. and Cohen, S.M. (1991 b):- Effects of in utero and postnatal sodium saccharin exposure on the nutritional status of the young rat 11 . Dose response and reversibility. Food Chem. Toxicol., 29(10): 669-679.

24. Gray, C.H., Howorth, P.J. and Rinsler, M.G.(1985):- Clinical Chemical pathology. $10^{\text {th }}$ ed., English Language Book Society. Edward Arnold, p. 73.

25. Hagiwara, A., Fukushima, S., Shibata, M. and Ito, N. (1984):- The effect of three sweeteners on rat urinary bladder carcinogenesis initiated by nitrosamine. Gann, 75(9): 763-768. 
26. Hassanin, N.I. (1998):- A study on the natural nutritive and non-nutritive sweenteners in rats. Veterinary Medical Journal, 46(2): 133-153.

27. Hassid, W.T. and Abraham, S. (1957):Determination of glycogen and Starch. In "Method In Enzymology". Colowick, S.P. and Kaplan, N.O. (Eds.), Academic Press, New York, p. 43.

28. Hertelendy, Z.I., Mendenhall, C.L., Rouster, S.D., Marshall, L. and Weesner, R. (1993):- Biochemical and clinical effects of aspartame in patients with chronic, stable alcoholic liver disease. Am.J. Gastroenterol, 88(5): 737-743.

29. Hinson, A.L. and Nicol, V.M. (1992):Monitoring sweetener consumption in Great Britain. Food Additives and Contaminants, 9: 669-681.

30. Horwitz, D.L., Mclane, M. and Kobe, P. (1988):- Response to single dose of aspartame or saccharin by NIDDM Patients. Diabetes Care, 11(3): 230-234.

31. Ismail, M.A. and El-Gabry, E. (1996):Sweetener commonly used in Egypt. Bull. Nutr. Inst. Cairo, Egypt. 16(1).

32. Ito, N., Fukushima, S., Shirai, T., Hagiwara, A. and Imaida, K. (1989):Drugs, food additives and natural products as promoters in rat urinary bladder carcinogenesis. IARC Sci. Publ., 56:399407.

33. Kamal, I.H., Moustafa, A.F., Abd ElGalil, A.M. and Abdullah N.M. (2000):Biochemical studies on alitame, a dipeptide non-nutritive sweetener on healthy and diabetic rats compared to aspartame. The New Egyptian Journal of Medicine, 23 (2):40-47.

34. Leon, A.S., Hunninghake, D.B., Rassin, D.K. and Telphy, T.R. (1989):- Safety of long term large doses of Aspartame. Arch Intern Med., 149:2318-2324.

35. Lewis, C.J., Park, Y.K., Dexter, P.B. and Yetley, E.A. (1992):- Nutrient intakes and body weights of persons consuming high and moderate levels of added sugars. J. Am. Diet. Assoc., 92: 708-713.

36. Lipton, W.E., Younoszai, M.K. and Stegink, L.D. (1991):- Degradation of bioactive substances. Metabolism, 40:13371345.

37. Marion, J. and Franz, M.S. (1993):- Use of nutritive and non nutritive swenteners. J. Am. Diet. Assoc., 93(7): 816-821.

38. Mitchell, M.L. and Pearson, R.L. (1991):Saccharin In: Alternative Sweeteners, Nabors, L.O. and Gelardi, R.C. (Eds.),
Marcel Dekker Inc., New York, Basel. Hong Kong, Ch. 8. p.127.

39. Mukhopadhyay, M., Mukherjee, A. and Chakrabarti, J. (2000):- In vivo cytogenetic studies on blends of aspartame and acesulfame-K. Food Chem. Toxical., 38(1): 75-77.

40. Murasaki, G. and Cohen, S.M. (1981):Effect of dose of sodium saccharin on induction of rat urinary bladder proliferation. Cancer Res., 41: 942-944.

41. Negro, F., Mondardini, A. and Palmas, F. (1994):- Hepatotoxicity of Saccharin. N. Engl. J. Med., 331(2): 134-135.

42. Okamura, T., Garland, E.M, Masui, T., Sakata, T. John, M.S. and Cohen, S.M. (1991):- Lack of bladder tumor promoting activity in rats fed sodium saccharin in AIN-76 A diet. Cancer, Res., 51:1778-1782.

43. Powers, M.A. and Laine, D.C. (1987):Sweeteners In: "Handbook of Diabetes Nutritional Management" Vol. II New York, Garland Press, p. 281.

44. Prasad, O. and Rai, G. (1987):Haematological abnormalities induced by feeding a common artificial sweetener, saccharin, in ICR Swiss mice. Toxicol Lett., 36(1): 81-88.

45. Reeves, P.G., Nielsen, F.H. and Fahey, G.C. (1993):- AIN-93 Purified diets for laboratory rodents: Final report of the American Institute of Nutrition Ad Hoc Writing Committee on the Reformulation of the AIN-76. A Rodent diet. J. Nutr., 123:1939-1951.

46. Reitman, S. and Frankel, S. (1957):- A colorimetric method for the determination of serum oxaloacetic and glutamic Pyruvic transaminases. Am. J. Clin. Pathol., 28: 56.

47. Reynolds, J.E. and Martindale, F. (1989):- The Extra Pharmacopoeia. $29^{\text {th }}$ ed. London: The Pharmacetuical press, p. 1273.

48. Rolls, B.J. (1991):- Effect of intense sweeteners on hunger, Food intake and body weight. Am. J. Clin. Nutr., 53:872878.

49. Sardesia,V.M. (1986):- Effect of aspartame in normal and diabetic rats. Biochemical Archives, 2:237-243.

50. Shakoori, A.R., Iqbal, M.Z., and Ali, S.S. (1995):- Biochemical and histopathological effects of saccharin on mouse liver. Pakiston. J. Zool., 27 (1): 1-13.

51. Snedecor, G.W. and Cochron, W.G. (1989):- Statistical methods, $8^{\text {th }}$ ed., Lowa State Univ. Press, Ames, Lowa, USA.

52. Spillance,W.J. (1996):- Molecular structure and sweet taste. In: "Advances in 
sweeteners", T.H. Grenby (Ed.), London, Glasgow, New York, p.1-25.

53. Sulik, M. (1974):- Morphologic and histochemical changes in lungs and liver of rats poisoned with agronex. Pathol., 25:2733.

54. Trinder, P. (1969):- Glucose measurement with enzymatic colorimetric method. Ann. Clin. Biochem., 6:24.

55. Van-Den-Eden, S.K., Koepsell, T.D. Longstreth, W.T. Jr, Van Belle, G., Daling, J.R. and Mcknight, B. (1994):Aspartame ingestion and headaches: a randomized crossover trial. Neurology, 44(10): 1787-1793.
56. Wardlaw, G.M. (2000):- Carbohydrates in foods. In "Contemporary Nutrition Issues and Insights". $4^{\text {th }}$ ed., MC Graw Hill, Boston, New York, San Francisco, p. 117120.

57. Wardlaw, G.M. and Kessel, M.W. (2002):- Carbohydrates. In "Perspectives In Nutrition". $5^{\text {th }}$ edition, Mc Graw Hill, Boston, New York, London, p. 189.

58. Williams, M.H. (2002):- Carbohydrates: The main energy food. In "Nutirition for Health, Fitness \& Sport. $6^{\text {th }}$ edition, Mc Graw Hill, New York, San Francisco, St. Louis, p. 145. 


\title{
التغيرات الفسيولوجية الناتجة عن إعطاء السكارين مقارنة بالأسبارتام

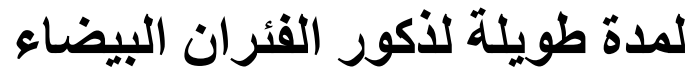

\author{
ايناس زيدان عبده عبد الله \\ قسم التغذية و علوم الاطعمة_ كلية الافتصاد المنزه لئ- جامعة حلوان
}

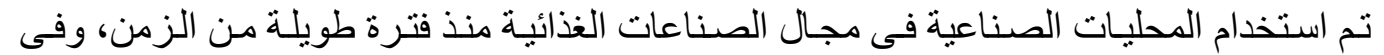

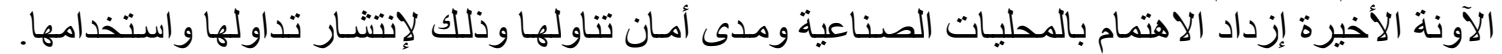

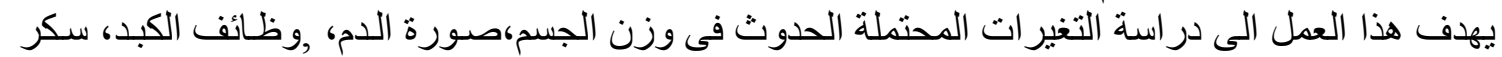

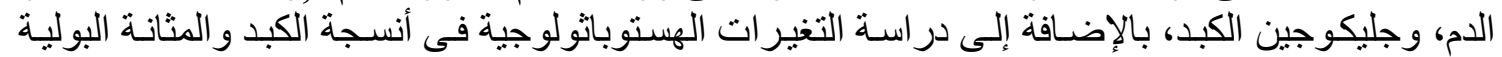

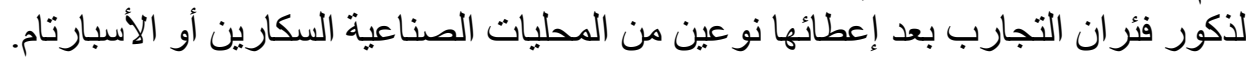

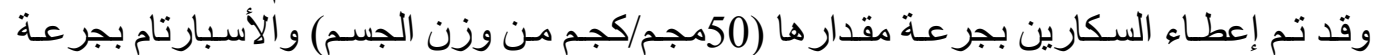

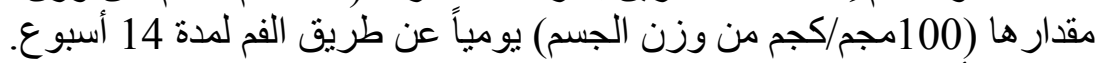

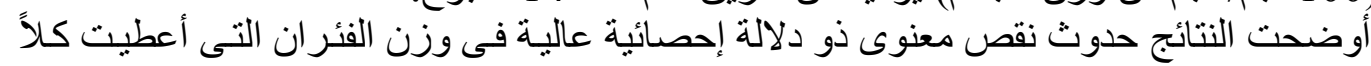

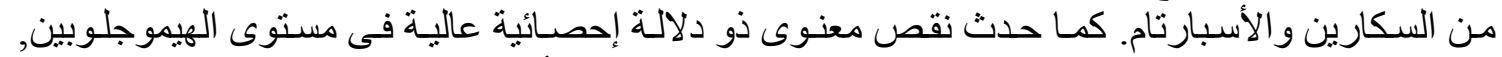

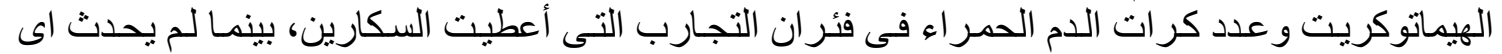

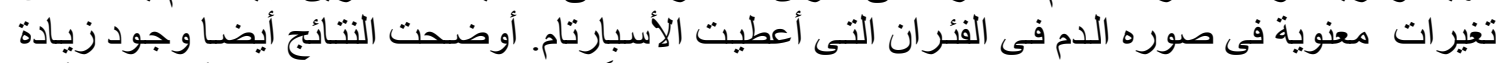

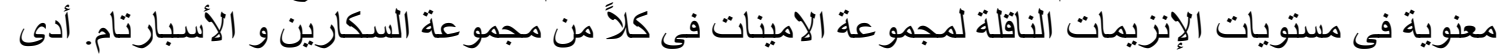

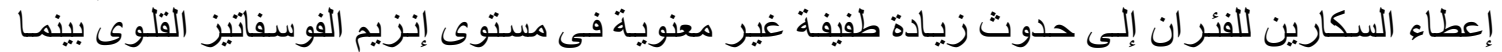

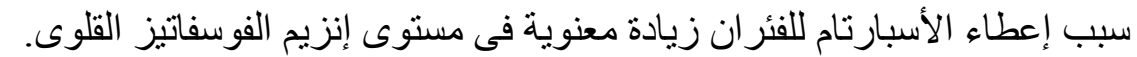

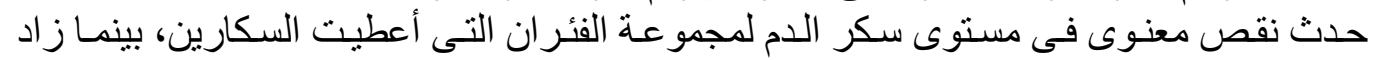

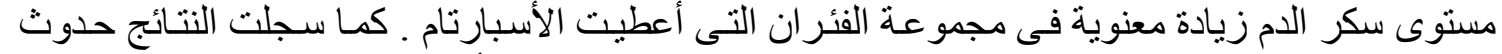

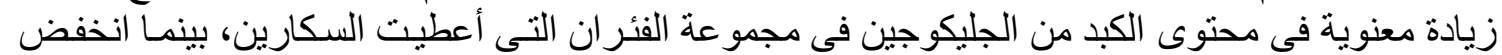

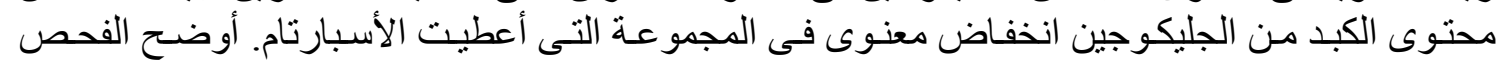

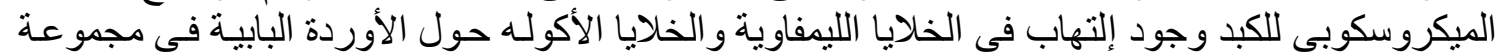

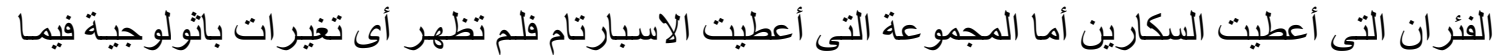

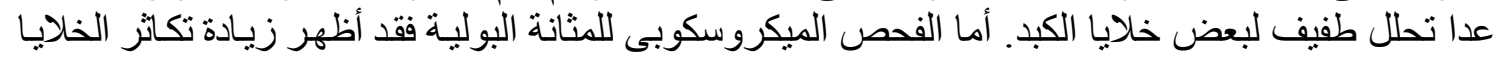

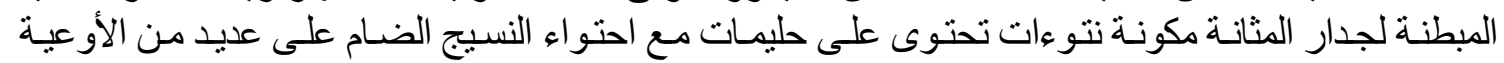

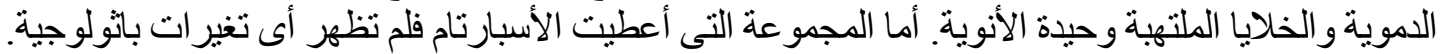

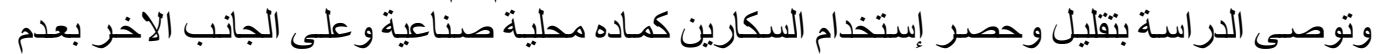

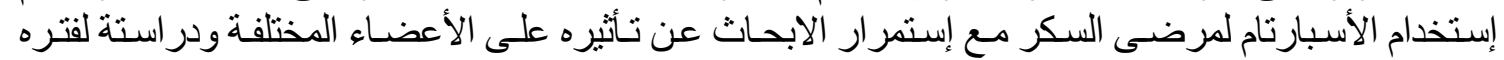

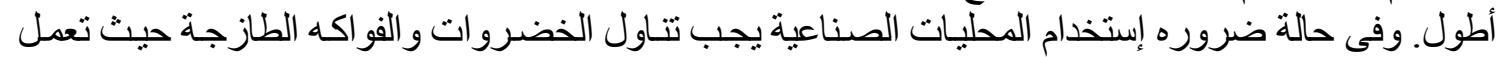

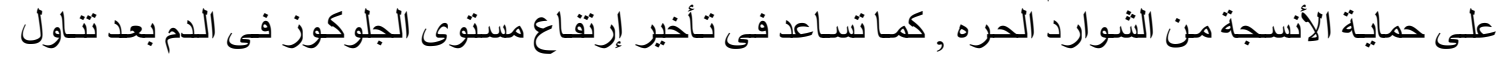

